\title{
A Review of the Eighth District's Agricultural Economy in 1986
}

\author{
Kenneth C. Carraro
}

\begin{abstract}
A tries in the Eighth Federal Reserve District. The District is home to important food and feed processing businesses in Arkansas and the St. Louis area, as well as the extensive agricultural transportation networks of the Mississippi, Missouri, Ohio, Arkansas and Tennessee-Tombigbee waterways. Ranging from famlevel production through farm inputs and commodity processing up to final comsumption, the agricultural sector accounts for mone than 20 percent of the nation's gross national product.' Because of the high concentration of agriculturally related business, agriculture likely accounts for an even higher percentage of total District output?
\end{abstract}

Eighth District agriculture consists of an extremely diverse mix of crops, including such traditionally "southern" crops as tobacco, rice and cotton as well as the Com Belt crops of soybeans and corn. Livestock production ranges from racehorses in Kentucky and the nation's largest broiler industry in Arkansas to the

Kenneth C. Carraro is an economist at the Federal Resenve Bank of St. Louis. Nancy D. Juen provided research assistance.

${ }^{1}$ Economic Report of the President, p. 148

The Eighth Federal Reserve District officially comprises all of Arkansas and parts of Illinois, Indiana, Kentucky, Mississippi, Missouri and Tennessee. In most cases, this aricle uses data for the entire states of Arkansas, Kentucky, Missouri and Tennessee to represent the District. Due to the availability of comprehensive bank firanclal data, the entire District is referred to in the section covering agriculural lenders. traditional hog and cattle operations throughout the entire region. This article provides an overview of District agricultural highlights in $1986 .^{3}$

\section{CROP HIGHLIGHTS}

\section{Production}

Since a very high number of farmers participated in government price support programs, which mandate acreage reduction, crop production dropped significantly in the District. The number of crop-acres harvested in the four states that make up the bulk of the District's economy - Arkansas, Kentucky, Missouri and Tennessee - fell from 32.3 million acres in 1985 to 30.8 million acres in 1986 , a drop of 4.7 percent. This decline followed a 5.5 percent decline in 1985 .

Weather conditions varied widely across the District. Tennessee, Kentucky and Arkansas suffered from particularly dry conditions early and midway through the growing season. This dryness was a by-product of the severe drought that was centered in the Carolinas and Georgia. While late season rains and favorable harvest conditions allowed major crops to recover to

\footnotetext{
3ata for crop and livestock production were derived from the annual reports of the four states' agricutural statistics services. Price data were obtanned from the USDA's Agricultural Outlook publication while farm income and assets data are from the USDA's Economic indicators of the Farm Sector. Sources of farm lender data are footnoted in the appropriate section.
} 


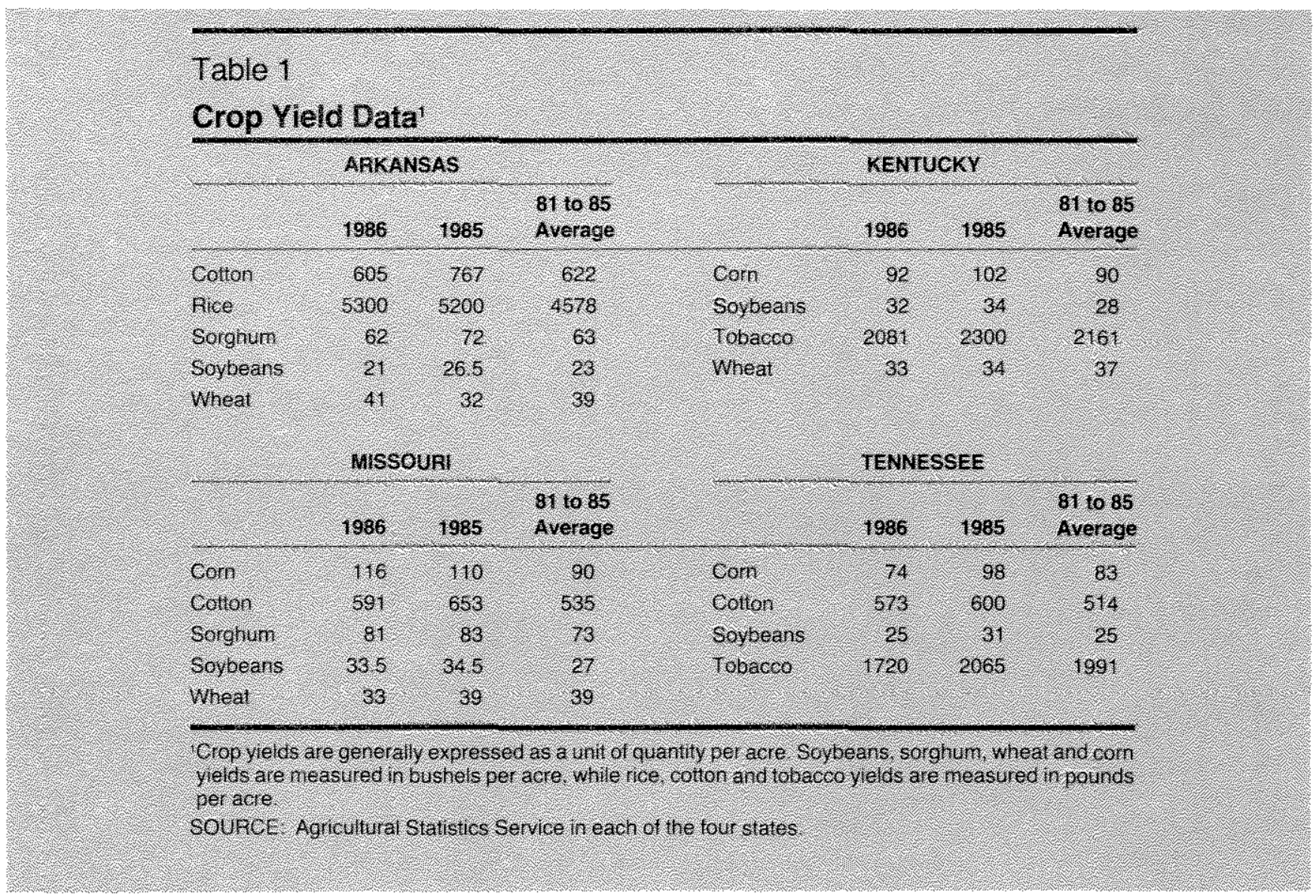

near their five-year average yields, the lower acreage resulted in overall reduced crop production in the District. Table 1 provides yield data for major crops in the four-state region for 1986,1985 and the five-year average yields from 1981 to 1985 .

In Akansas, rice and wheat yields surpassed both their 1985 yields and their yield patterns of the past five years. Total rice production increased by .9 percent in 1986 . Vields of other major crops in the state, such as soybeans, sorghum and cotton, were below their 1985 levels but near the average yields over the past five years. Total soybean production in the state was 29.3 percent lower in 1986 than in 1985 because of lower yields and smatler acreage.

Yields of all major crops in Kentucky were below the yields of 1985 but were near the five-year average yields. Total production of the state's most valuable crop, tobacco, was down 22.7 percent because of production controls and dry weather. The federal price support program for tobacco, which controls its production, was primarily responsible for a 14.6 percent decline in harvested acreage, while dry weather caused below-average yields. Soybean yields, which benefited most from the late-season favorable weather, were above theiv five-year average, while most other crops were close to their five-year average.

Of the four states, Tennessee was the most severely affected by the year's dry weather. Yields of all major crops were below their 1985 levels. Cotton yields. however, were above the average of the past five years. The soybean yield was approximately at the longerterm average for the state while corn, tobacco and most other crop yields were below their five-year averages. Soybean production in 1986 was 17.1 percent lower than in 1985, while corn production was 28.2 percent lower than 1985 due to smaller yields and reduced acreage for both crops.

Missouri crop famers benefited from the most favorable weather in the District. All crop yields in 1986 , except for wheat, were above their five-year averages. The 1986 corn yield of 116 bushels per acre was significantly higher than the previous record set in 1985. Total com production was 2.9 percent higher. Sorghum yields were slightly below their record yields of 1985. Although 200,000 acres of soybeans were lost to late-season flooding, soybean yields were also at near- 


\section{Chart 1 \\ Crop Price Comparisons}

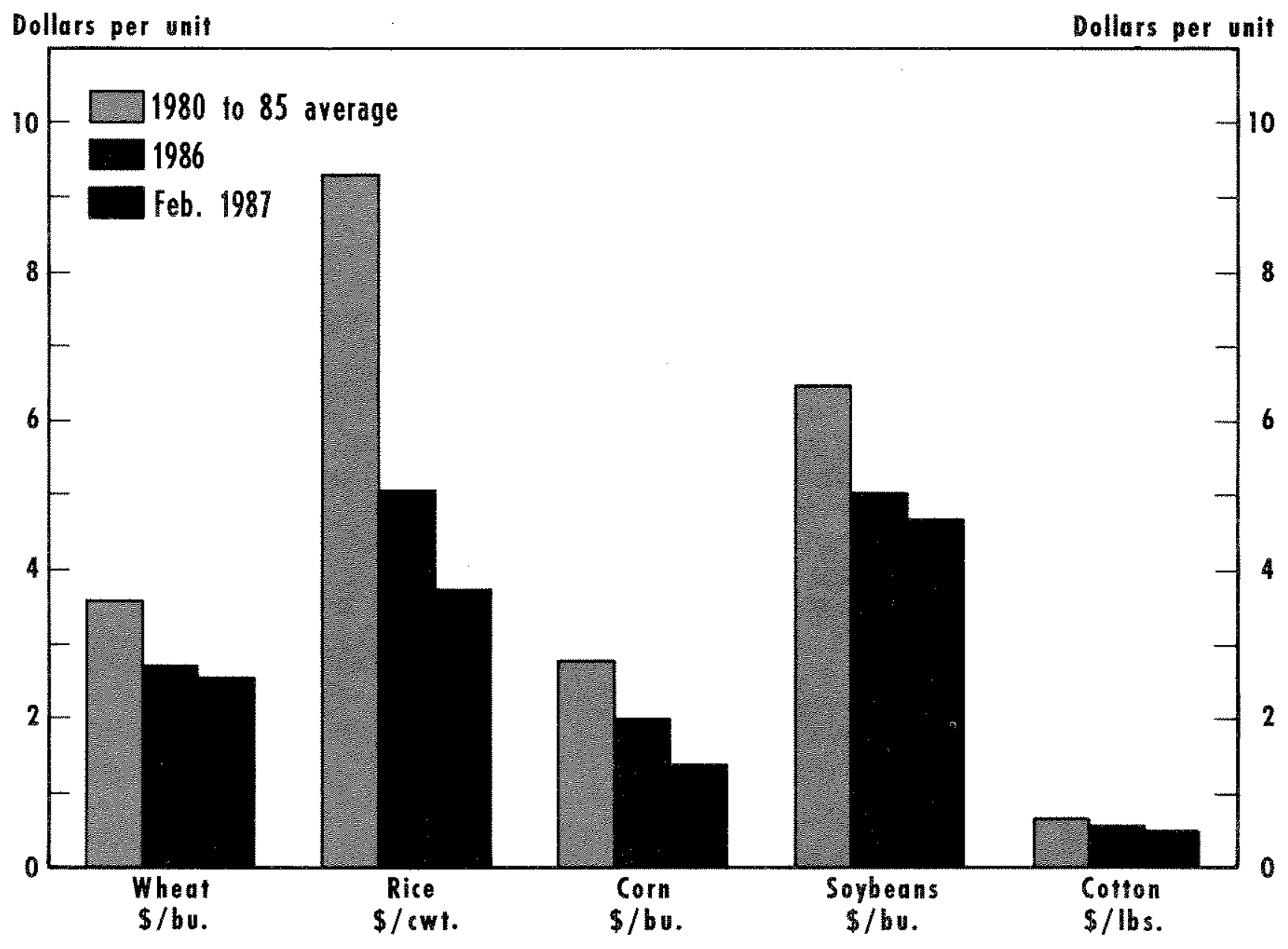

record levels in the state. Total soybean production was only 1.6 percent smaller in 1986 than 1985.

\section{Prices}

Prices of food and feed grains fell sharply, despite the lower average levels of output nationally. Soybean and other oilseed crop prices were also below 1985 levels.

Chart 1, which compares the prices for major crops in the Eighth District, shows that prices in 1986 were below the average prices over the $1980-85$ period. Moreover, the most recent crop prices (February 1987) indicate that the pattern of falling prices has continued.
Sharply lower levels of price support loans provided by the discretionary authority of the 1985 Farm Bill were primarily responsible for the crop price dedines. The loan levels usually provide a lower bound for commodity prices. Chart 2 shows how the market price for corn has fallen as the loan support price was lowered sharply over the past two years. Food grain prices fell 18.0 percent from 1985 levels; feed grain prices were down 21.3 percent.

For some crops, such as corn and wheat, market prices have declined to levels well below their price support levels. Some analysts have attributed this to the government's use of generic commodity certificates in lieu of direct cash payments to farmers to reduce stocks of government-owned commodities 


\section{Chart 2}

\section{Corn: Target Price, Loan Rate and Market Price}

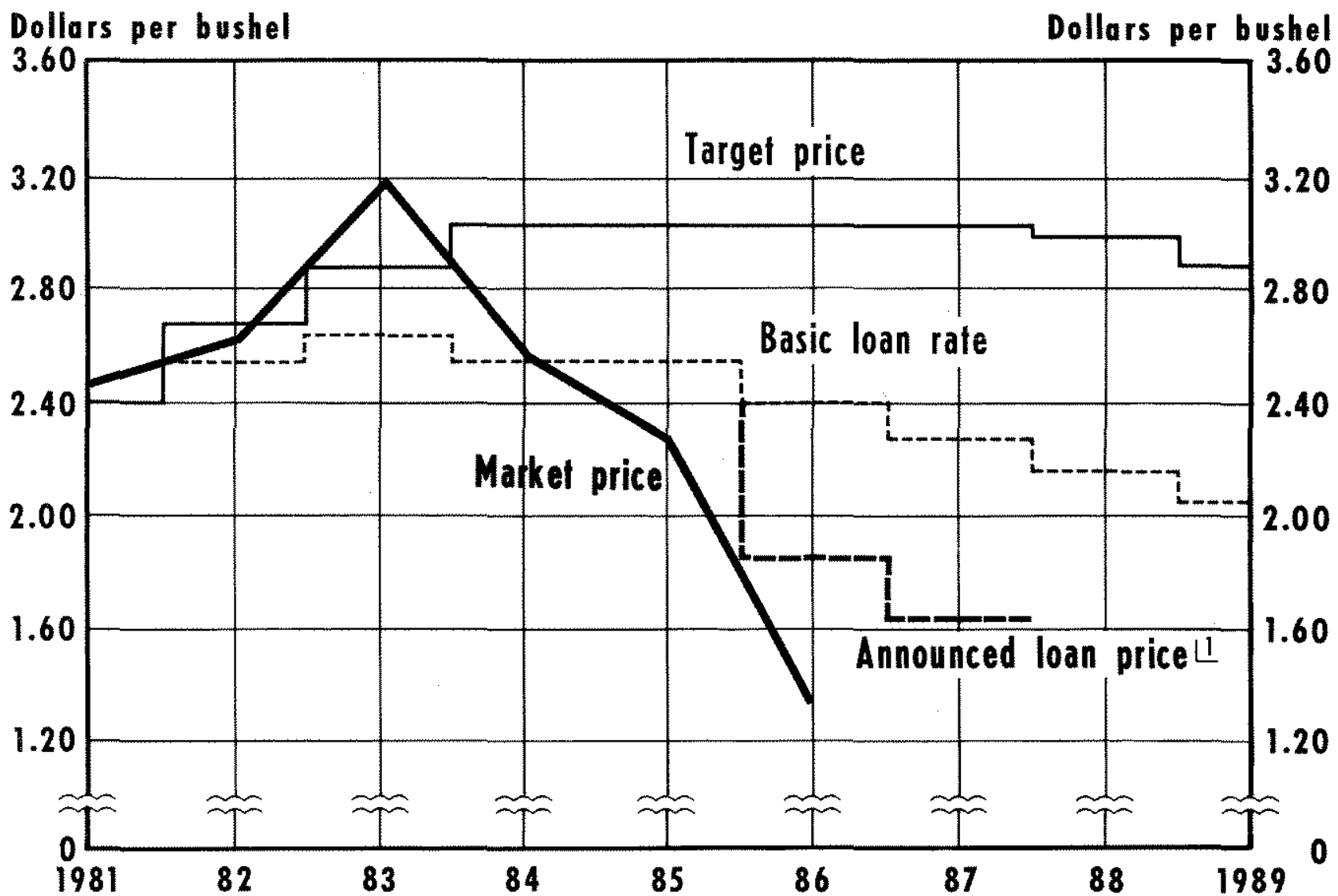

$\lfloor$ Set by the Secretary of Agriculture within mandated limits.

Source: U.S. Department of Agriculture. See Economic Report of the President 1987, p.154.

(see shaded box on opposite page for more informa tion). The certificates have a stated value and allow the holder to receive commodities stored by the Commodity Credit Corporation (CCC). The commodities then may be sold at prevailing market prices. The release of government stockpiles tends to increase market supply and reduce market prices.

Soybean prices also were below 1985 levels despite lower total production in 1986 primarily because of the large stocks that have been accumulated in the United States. As chart 3 indicates, while soybean stocks held elsewhere in the world remained level over the last eight years, U.S. stocks of soybeans have grown shapply since 1983 when a drought and the
Payment-In-Kind (PIK) program reduced stocks sharply.

\section{LIVESTOCK HIGHLIGHTS}

\section{Production}

District cattle and calf production, which declined in both 1984 and 1985 , bounced back in 1986, increasing by 2.2 percent. Cattle and calf production increased in Arkansas and Kentucky, while declining in both Missouri and Tennessee. District hog production, which also declined in 1984 and 1985, continued its descent, closing at 6.5 percent lower in 1986 than in 


\section{Generic Commodity Certificates}

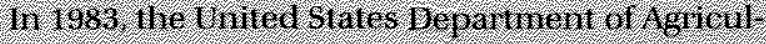

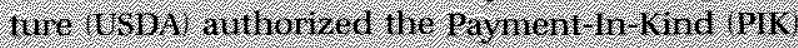

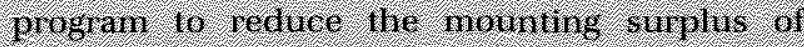

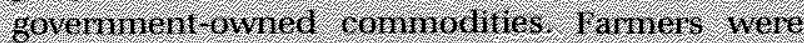

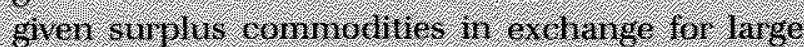

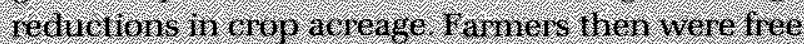

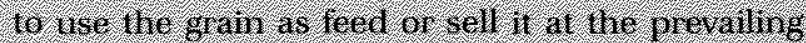

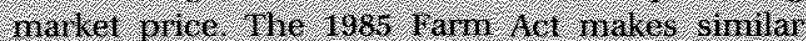

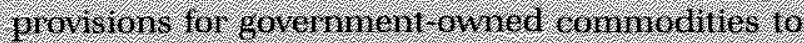

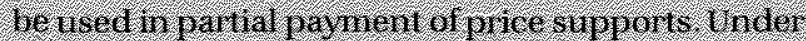

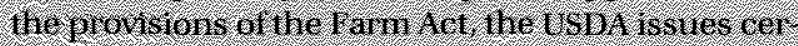

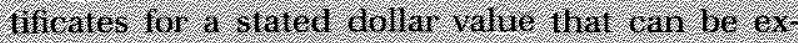

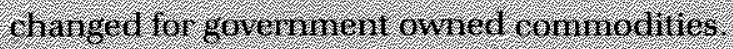

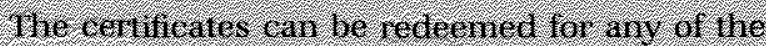

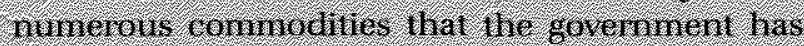

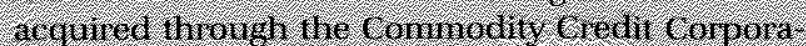

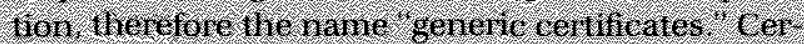

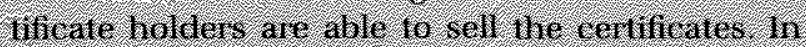

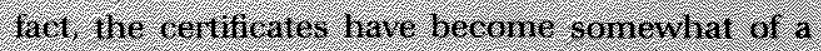

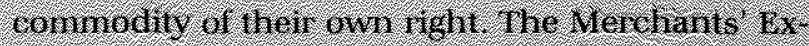

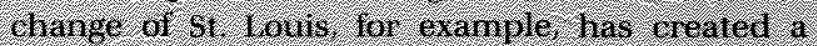

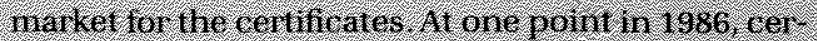

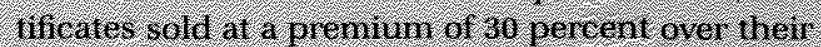
Ree vallo.

one important eted or the rerificates has bern

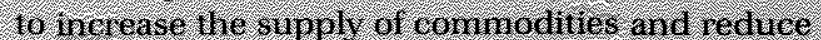

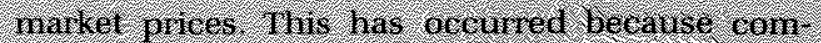
mudmes hat allewwise would hor be avalable to the matret wider the provisions of the goveriment

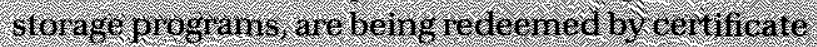
holders atnd sold or the havker h he mochianios of

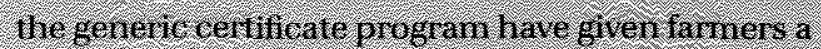

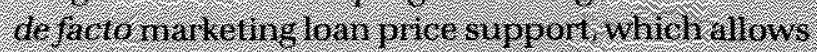

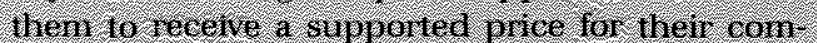

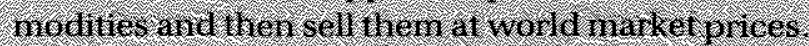

Chart 3

\section{Soybean Carryover Stocks}

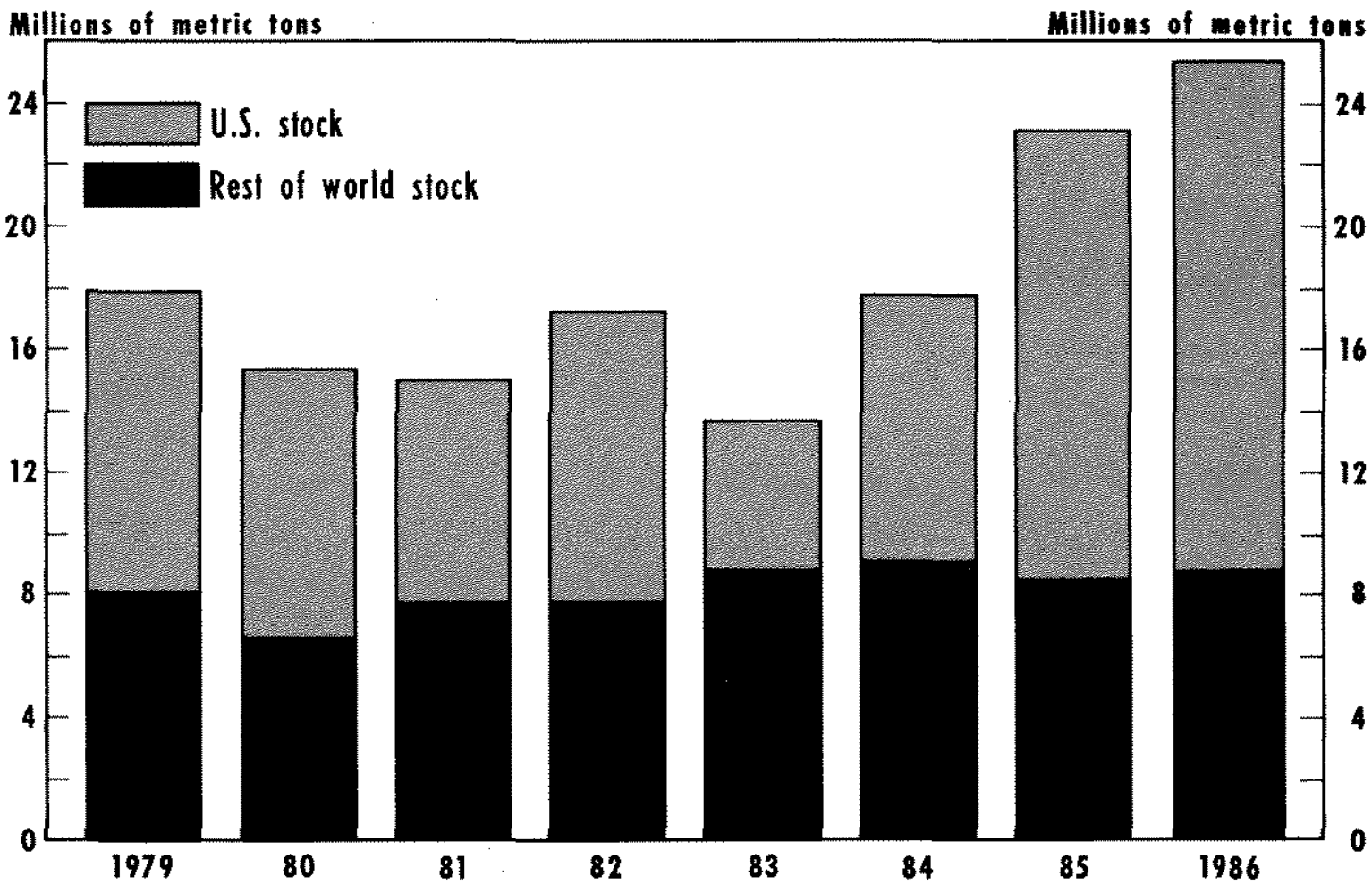




\section{Chart 4}

\section{Livestock Price Comparisons}

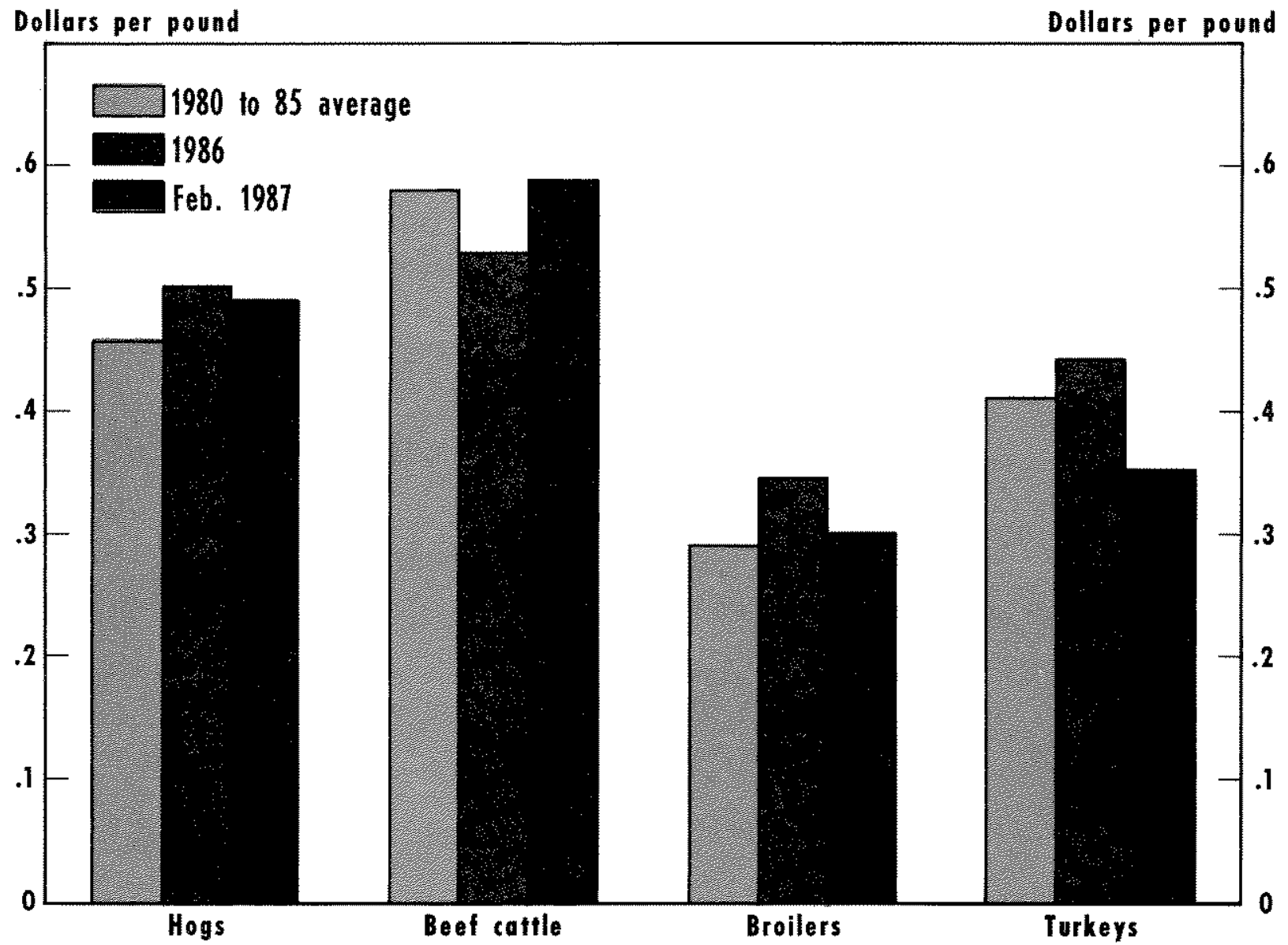

1985. Missouri, the most important hog-producing state in the District, showed a decline of 10.9 percent from 1,234 million pounds in 1985 to 1,099 million pounds in 1986.

Poulty production continued to grow, especially in Arkansas, the nation's leading producer of broilers. Broiler production accounts for over 25 percent of all farm cash receipts in Arkansas. Turkey production in Missouri also has exhibited strong growth ove" the past two years.

\section{Prices}

Livestock prices remained below 1985 levels through the first half of 1986, but price hikes during the second half boosted the price index of meat animals up 2.1 percent in 1986 . As chart 4 shows, over a longer-tem perspective, all major livestock groups except beef cattle registered prices in 1986 that were higher than the average price over the 1980-85 period. In addition, both beef cattle and hog prices in early 1987 have remained near or above their 1986 average levels.

\section{FARM FINANCES}

Nationally, total net farm income has been estimated at $\$ 33$ billion to $\$ 37$ billion in 1986 , up from $\$ 30.5$ billion in 1985. Sharply lower production costs are responsible for the increase. Net farm income is forecast at the same level for 1987. Chart 5 shows the relationship between the growth of District net farm income and national net farm income growth from 1977 to 1985 . Although 1986 net farm income data for 
Chart 5

\section{Net Farm Income Growth}

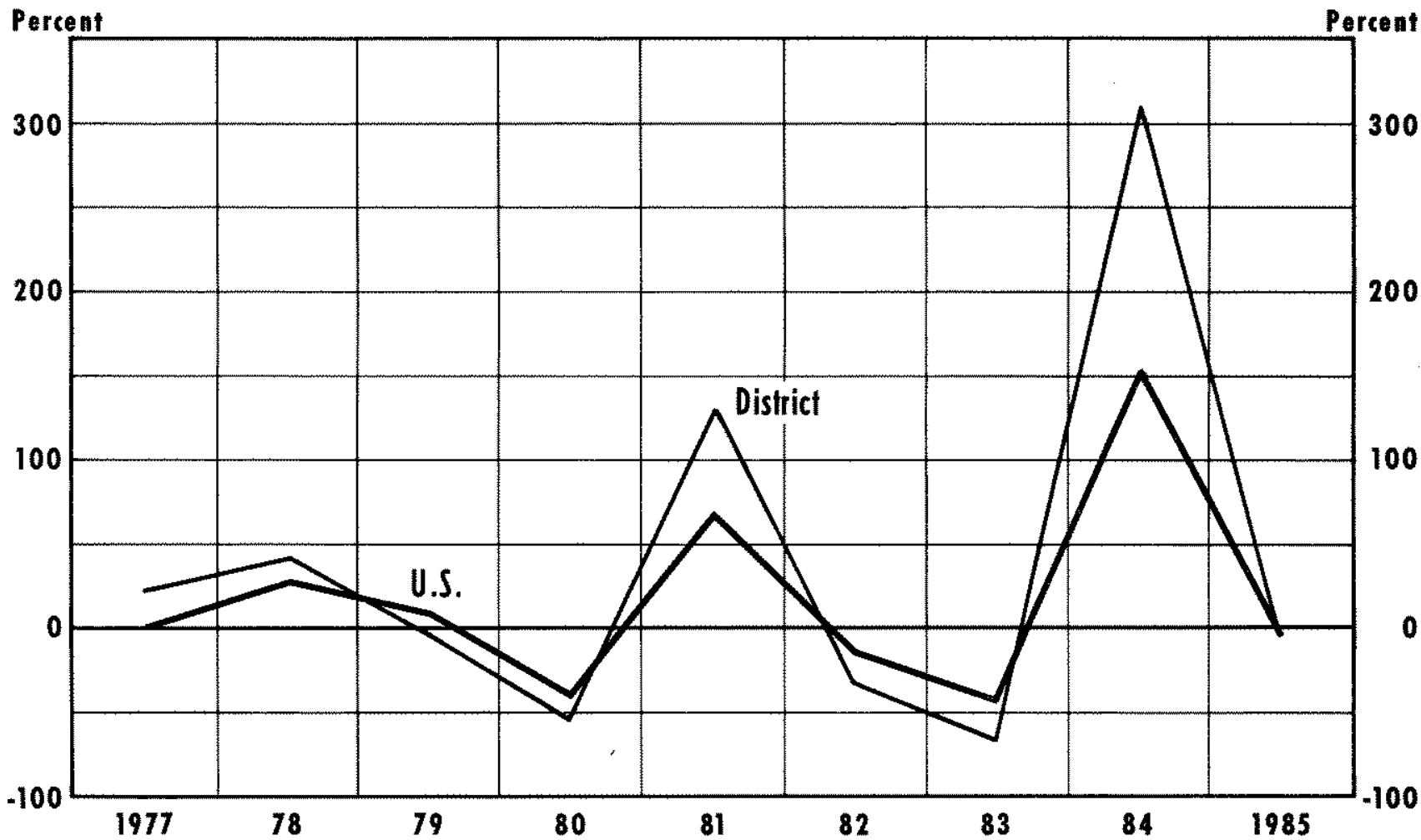

individual states will not be available until this fall, the close relationship between changes in national and District farm income suggests that District net farm income also rose in 1986 and will be unchanged in 1987.

Govemment payments accounted for a growing share of farm income both nationally and District wide. Nationally, government payments of $\$ 12$ billion represented approximately 34 percent of total net farm income in 1986; they are expected to grow to $\$ 16$ billion this year, almost half of projected net farm income.

In 1985 , farmers in the four-state District region received payments of $\$ 626$ million. This figure repre-

"When net farm income data are adjusted for inflation, it becomes apparent that farm income has been declining since Worid War II, with the exception of the early 1970s. See Belongia (1986) for a detailed examination of the long-term decine in the farm sector. sented 20.1 percent of net farm income for the year. Government payments to District farmers were undoubtedly even larger in 1986, for several reasons. First, price support loan levels were lowered, while target prices were unchanged. The wider gap between target and support prices caused a larger proportion of crop payments received by farmers to come from direct government payments. Second, under a marketing loan program for rice and cotton, which are major crops in Arkansas, Missouri and Tennessee, farmers repaid their price support loans at the lower world commodity price rather than at the higher price they received for the original crop loan. This, of course, implicitly allowed farmers to keep a portion of their original CCC loan as a direct support payment.

Meanwhile, farm production expenses dropped for the second consecutive year in 1986. Lower levels of farm debt, lower interest rates on such debt and reduced expenses for production inputs contributed to the reduction. The chief areas of input price declines 


\section{Chart 6}

\section{Total Farm Assets}

\section{Arkansas, Kenfucky, Missouri and Tennessee}

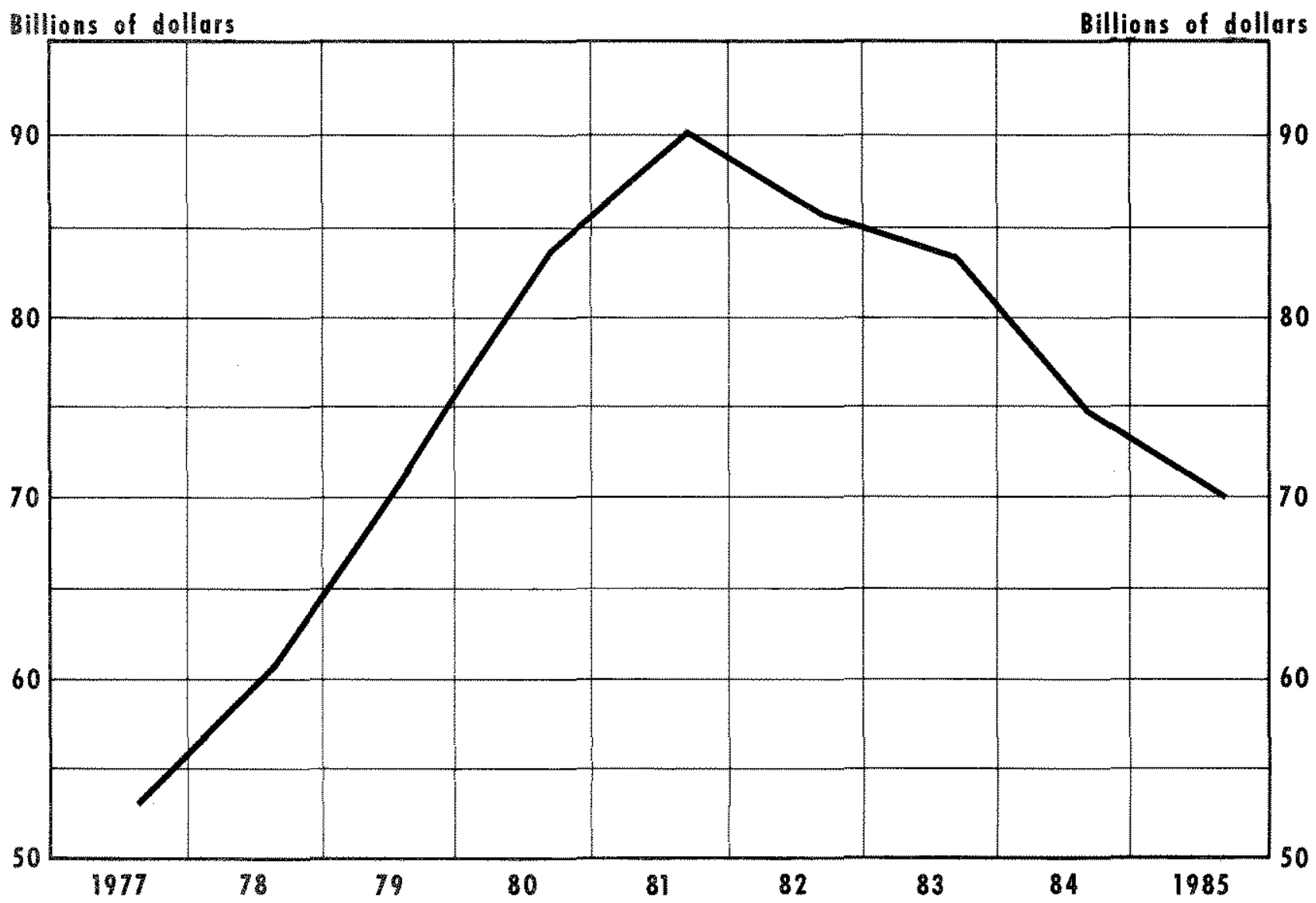

were petroleum lused for fuel, fertilizers and chemicalsi and feed grains lused for animal feed).

As chart 6 shows, the value of total farm assets in the four-state region of the District has been declining steadily since 1981. In 1986, land values in the District continued to decline in Arkansas, Kentucky and Missouri, but increased in Tennessee. Table 2 indicates that, of the four-state region, Arkansas experienced the largest land value decline in 1986, while Missouri had the largest decline since the 1981-82 peak.

\section{FARM LENDERS}

The overall volume of fam loans outstanding in the District continued to decline in 1986 . This secular decline is associated with lower input costs, falling land values, increased government payments, and the weakened financial position of many farm borrowers.

The two most important sources of credit for farmers in the District are agricultural banks and the Farm Credit System (FCS), "The volume of farm loans outstanding af District agricultural banks increased by

5Agriculitural banks are considered to be commercial banks with above average percentages of farm loans. At the end of 1986 , agricultural banks were those with more than 16 percent of their total loans in farm loans. All bank data are derived from banks' end-ofyear Reports of Conditions and Income, which FDIC-insured banks must file. The FCS has offices in St. Louis and in Louisville. The St Louis District covers the entire states of Arkansas, Illinois and Mis. souri. The Louisville Disirict includes Indiana, Kentucky, Ohio and Tennessee. 


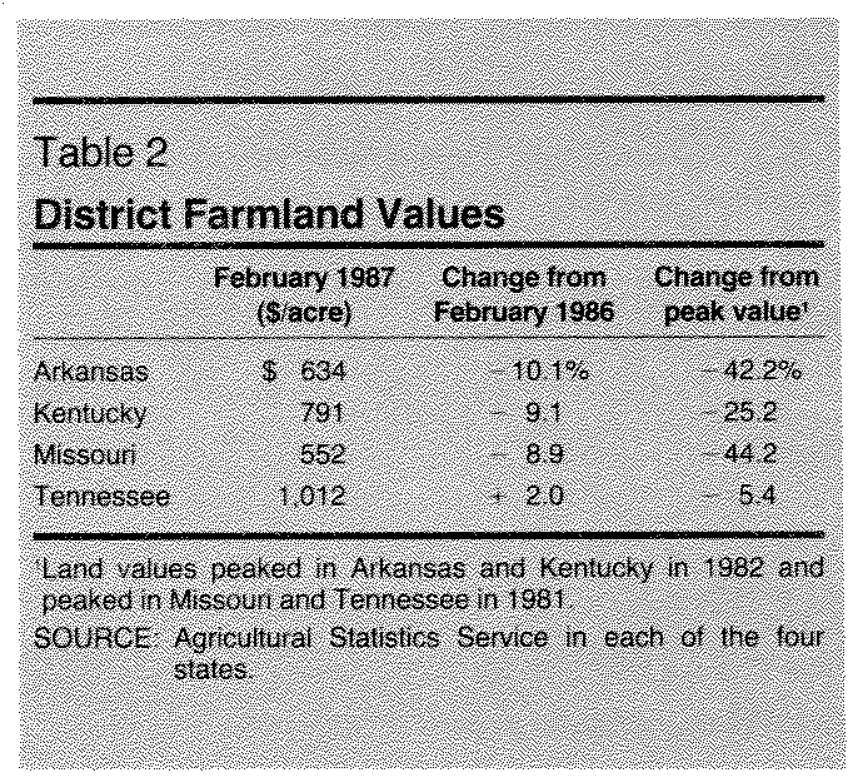

9 percent from 1985 but was 6.1 percent lower than in 1984. The slight increase at agricultural banks in 1986 can be attributed to the 13.1 percent growth in fam loans secured by farm real estate.

Total farm loans outstanding at the two FCS Districts fell by 19.4 percent from 1985 and by 34.3 percent from 1984, a much steeper drop than for most other farm lenders. These declines in the share of farm debt held by Farm Credit system lenders may be influenced by factors such as the higher interest rates charged by FCS lenders relative to commercial barks or concern on the part of RCS borrowers over the possible loss of value of borrower stock.

According to preliminary data, the fnancial condi tion of agricultural banks in the District has begun to mprove. The delinquency rate on all loans at District agricultural banks fell from 6.4 percent at the end of 1985 to 5.8 percent at the end of 1986 . The deinquency rate on agricultural loans fell from 6.6 percent of lotal farm loans outstanding at the end of 1985 to 5.4 percent at the end of 1986. The proportions of total loans and agricultural loans charged off at agricultural

Metichar (1987) cites a Federal Feserve survey indicating that most of the rew farm loans secured by real estate have short maturities and are for farm operating or other non-real-estate purposes. This suggests that bankers may be demanding farmland as collateral for operating and machinery loans.

The detinquency rate includes loans that are 30 days or more pastdue as well as nonaccrual loans. The agricultural loan delinguency rate is calculated as delinquent agricultural loans over the sum of farm non-reat-estate loans and farm real-estate loans outstanding. The delinquency rates on all loans and agricultural loans declined at agricultural banks in each of the District states except Mississippi where both rates increased slightly. banks, while up sharply in 1985, dechned slighty in 1986.

An additional indication of this improvement can be found in the number of agricultural banks at which the volume of past-due and nonacoual loans exceeds bank capital and loss reserves. Most banks that failed in 1986 reported past-due and nomaccrual loans in excess of the bank's capital and reserves. The number of agricultural banks in this position, which had been steadily increasing for a number of years, peaked in 1985; by the end of that year; 17 agricultural banks in the District were in this condition. Only 11 such Disfrict agricultural banks fell into this category in 1986. Moreover, only three District agricultura banks faled last year'.

Profitability at District agricultural banks, as measured by banks' retum on assets and retum on equity, improved in 1986 after stabilizing in 1985. Prior to 1981, agriculturel banks generally had enjoyed significanty stronger earnings than similar-sized nonagricultural banks. Since 1981, however, the earnings gap between these kinds of banks frst narrowed and then was eliminated because of rising loan losses and provisions to cover these loan losses at agricultural banks. Chart 7 plots the proffability of nonagricultural banks and similar-sized agricultural banks. ${ }^{*}$

While agricultural banks have shown some improvement, problems at the wo Farm Credit Distucts in the area have continued to worser. The rate of nonaccruat and restructured loans at the two fCS Districts combined rose from 9.3 percent of all loans at the end of 1985 to 14.3 percent at the end of 1986 . The combined rate of loans charged off at the wo Districts rose from 1.8 percant to 2.5 over the same period.

\footnotetext{
This comparison was made by firsl calculating the average size and standard deviation for agricultural banks. Banks were restricted to those smaller than the average agriculutura bank size plus one-hall standard devialion. For 1986 , this size limit was $\$ 57.9$ million in total bank assets. Nonagricuitural banks include banks with an agricultural loan to total loan ratio of less than 5 percent.

${ }^{9}$ This rate is not stricly comparable to the delinquency rate for commercial banks. It is calculated as the sum of nonacorual and restructured loans over total loans outstanding for the Federal Land Banks, the Federal Intermediate Credit Banks and the Banks for Cooperatives. In all cases, the amount of restructured loans are extremely small relative to the nonaccrual loans. These data are derived from the annual reports of the St. Louis and Louisville FCS Districts. When more complete data from the Farm Credit Administration's Summary Report of Conditions and Performance are used, the rate of nonperforming loans rose from 13.5 percent on Septem ber 30,1985 , to 24.6 percent one year later. Nonperforming loans include nonaccrual and restructured loans plus "other highrisk loans."
} 
Chart 7

\section{District Bank Profitability \\ Refurn on Assets}

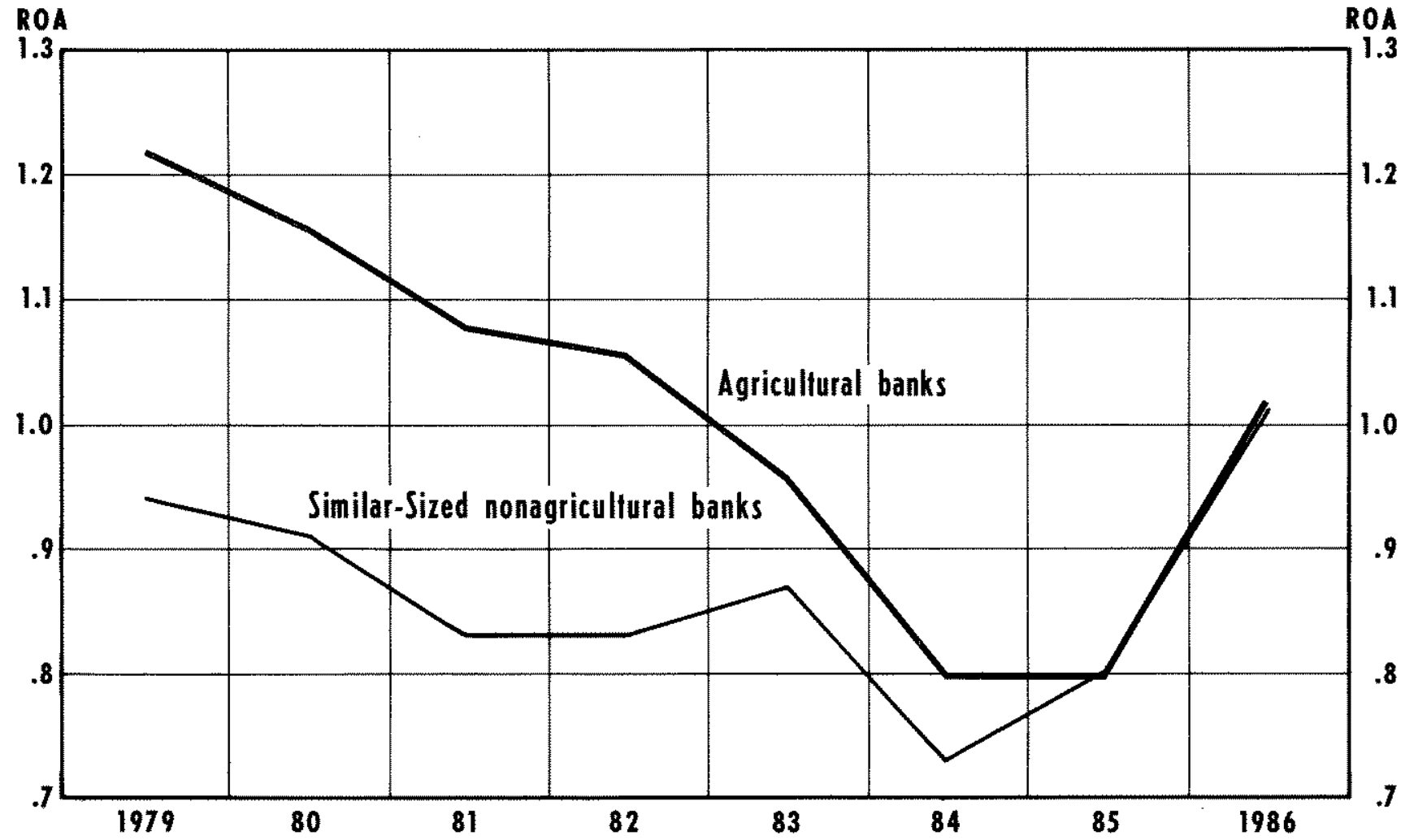

Although loan chargeoffs increased in the District, total net income improved at the local FCS lenders. Losses at the Farm Credit Banks of St. Louis were $\$ 121$ million in 1986, down from $\$ 254$ million in 1985 . Losses at the Farm Credit Banks of Louisville fell from $\$ 294$ million to $\$ 101$ million over the same period. Nationally, losses at the Farm Credit System were $\$ 1.9$ billion for all of 1986, down from the $\$ 2.7$ billion loss in 1985 .

While losses have decreased both nationally and locally, the capital of the Federal Land Banks in both St. Louis and Louisville has been reduced to the point that their stock, which borrowers must purchase to obtain a loan, has become impaired. This means that, under generally accepted accounting principles, the stock's book value is less than the $\$ 5$ full par value. Currently, the stock is being redeemed at full par value thanks to the use of regulatory accounting principles that were permitted under the Farm Credit Act Amendments passed by Congress in 1986.
Both the St. Louis and Louisville Farm Credit Banks called upon the loss sharing provisions of the Farm Credit System to receive financial assistance from other entities of the System in 1986. The Federal Land Bank of Louisville received $\$ 140$ million (net) from other institutions, while the Louisville Federal Inter mediate Credit Bank and Bank for Cooperatives were net contributors of financial assistance under the System's Bank Capital Preservation Agreement. The Federal Land Bank of St. Louis received $\$ 15.6$ million in financial assistance but contributed $\$ 18.4$ million to other institutions. The other two St. Louis FCS banks were net contributors as well.

\section{SUMMARY}

District agricultural conditions in 1986 exhibited a large degree of variability due to weather conditions. While record yields of some major crops occurred in 
Missouri, Tennessee yields were below average due to dry weather. In general, however, District-wide yields were near their five-year trend levels.

Government farm policy had a major effect on agriculture. In part because of govemment price support programs that require acreage reductions, harvested acreage fell by 4.7 percent in 1986 after falling 5.5 percent in 1985. Despite the reduced acteage, crop surpluses continued to mount causing cep prices to fall. Falling crop prices in turn led to high levels of direct government price support payments, Such payments to District farmers were particularly high for cotton and rice, the two crops supported by the gov" ernment's marketing loan program.

While crop producers were faced with falling market prices, livestock producers experienced steady or rising prices and increasing profits due to lower feed costs.

As was true for the nation, District net farm income is predicted to increase from 1985. Farm debt continued to decrease in 1986 as a result of lower production levels and lower input costs, Despite the lower debt levels, farmers' debt-to-asset ratios have deteriorated because of falling asset values.
During 1986, agricultural banks generally reversed a fve-year pattem of declining profitability and rising delinquency rates. While the Farm Credit System had smaller losses in 1986 than in 1985, loan delinquency rates rose sharply and the two local Farm Credit System Districts required financial assistance from other Districts.

\section{REFERENCES}

Belongia, Michael T. "The Farm Sector in the 1980s: Sudden Collapse or Steady Downturn?" this Review (November 1986), pp. $17-25$.

Economic Repot of the President 1987. (U.S. Government Printing Office, 1987).

Farm Credit Administration. "Summary Report of Condition and Performance of the Farm Credit System," Quarter Ending September 30,1985 and 1986.

Melichar, Emanuel. "Farm Credit Developments and the Financial Condition of Agricultural Banks" a preliminary report for the National Agricultural Credit Committee (Board of Governors of the Federal Reserve System, March 16, 1987).

U.S. Deparment of Agricutture. Economic Fesearch Service, Agricultural Outlook, various dates.

Economic Research Service, Economic Indicators of the Farm Sector, various dates. 